\title{
ROS Receptor Tyrosine Kinase: A New Potential Target for
}

\section{Anticancer Drugs}

\section{Ibrahim Mustafa El-Deeb, ${ }^{1,2}$ Kyung Ho Yoo, ${ }^{1}$ So Ha Lee, ${ }^{1}$}

\author{
${ }^{1}$ Life / Health Division, Korea Institute of Science and Technology, P.O. Box 131, \\ Cheongryang, Seoul 130-650, Republic of Korea \\ ${ }^{2}$ Department of Biomolecular Science, University of Science and Technology, 113 Gwahangno, \\ Yuseong-gu, Daejeon 305-333, Korea
}

Correspondence to: So Ha Lee, Life Sciences Research Division, Korea Institute of Science and Technology, P.O. Box 131, Cheongryang, Seoul 130-650, Republic of Korea, Tel.: +82 2958 6834; fax: +82 29585189 ; e-mail address: LSH6211@kist.re.kr 
Abstract: ROS kinase is one of the last two remaining orphan RTKs with a yet unidentified ligand. The normal functions of human ROS kinase in different body tissues have not been fully identified so far. However, the ectopic expression, as well as the production of variable mutant forms of ROS kinase has been reported in a number of cancers, such as glioblastoma multiforme, and non-small cell lung cancer, suggesting a role for ROS kinase in deriving such tumors. It is thought also that c-ROS gene may have a role in some cardiovascular diseases, and the fact that homozygous male mice targeted against c-ROS gene are healthy but infertile, has inspired researchers to think about ROS inhibition as a method for development of new male contraceptives. The recent discovery of new selective and potent inhibitors for ROS kinase, along with the development of new specific diagnostic methods for the detection of ROS-fusion proteins, raises the importance of using these selective inhibitors for targeting ROS mutations as a new method for treatment of cancers harboring such genes. This review focuses on the ectopic expression of ROS and its fusion proteins in different cancer types, and highlights the importance of targeting these proteins for treatment of substantial cancers. It describes also the recent advances in the field of ROS kinase inhibition, and the potential clinical applications of ROS kinase inhibitors.

Key words: ROS; glioblastoma; receptor tyrosine kinase; cancer; NSCLC

\section{INTRODUCTION}

Receptor tyrosine kinases (RTKs) are important players in the process of signal transduction and cellular communication. They act as the cell surface receptors for a number of important growth factors and hormones. ${ }^{1}$ In addition to the vital role of these RTKs as regulators for normal cellular processes, they also have another dark side presented by their key roles in the initiation and progression of a number of cancers. In these types of cancers, gene translocations resulting in kinase fusion proteins with constitutive and uncontrolled activity are so common. ${ }^{2}$

A famous example for kinase fusion proteins is the Bcr-Abl oncoprotein, a non-receptor tyrosine kinase, which was identified as the most common translocation event in chronic myeloid leukemia (CML) with an incidence percent of more than $90 \%$ in CML patients. ${ }^{3}$ A number of gene translocations leading to the production of fusion proteins in a variety of other cancers have also been reported. ${ }^{4}$ The identification of translocations and mutations in human cancers is of great importance, since it can lead to the development of new therapeutics that target such fusion or mutant proteins selectively, providing new more selective and less toxic anticancer drugs. 
It's much helpful also in providing new selective and sensitive diagnostic tools for identifying patients harboring such gene mutations or translocations allowing for their early treatment before progression of the cancer into a more complicated phase. Referring again to the example of Bcr-Abl translocation in CML patients, it's noteworthy to mention that the development and approval of Gleevec (Imatinib mesylate, STI-571) ${ }^{5}$ as the first kinase inhibitor to be used as an anticancer drug that selectively targets Bcr-Abl fusion protein for treatment of CML, has opened a new stream in the field of development of new selective therapeutics for treatment of certain cancers. This drug is the first of a new class of anti-proliferative agents designed to interfere with the signaling pathways that derive the growth of tumor cells. The development of this drug represents a significant advance over the classical therapies for CML. The use of conventional chemotherapies and radiation which lack the selectivity of targeting cancerous cells, results in serious side effects and is often of limited usefulness, since it fails to specifically target the underlying causes of malignancies. Accordingly, there is a continuous desire to identify new gene translocations or mutations that are responsible for the production of fusion or mutant proteins implicated in the progression of human cancers.

There are 58 RTKs in humans that belong to 20 distinct families, ${ }^{1,2}$ among these kinases is 'ROS kinase', which is one of the last two remaining orphan RTKs, since its ligand is yet unidentified. During the last 25 years, extensive work has been made for the identification and characterization of ROS RTK and its encoding gene, however, the first and the only review available so far about ROS kinase was published recently by Acquaviva et al. ${ }^{6}$ That review has addressed the different roles of ROS kinase in normal and cancerous tissues, its distribution in different body organs and hypothesized some possible methods for the discovery of its unidentified ligand. In this review we focus mainly on the mutagenic transformations in ROS gene and the resulted fusion proteins as possible targets for new selective anticancer drugs. This review addresses also the recent discovery of selective ROS kinase inhibitors, ${ }^{7,8}$ and the possible and potential applications for such inhibitors.

\section{2. c-ROS GENE AND ROS PROTEIN}

c-ROS gene was first discovered in 1986 when a recombinant DNA clone containing cellular sequences homologous to the transforming sequence, v-ROS, of the avian sarcoma virus UR2 ${ }^{9-11}$ was isolated from a chicken genomic DNA library. ${ }^{12,13}$ UR2 sarcoma virus is a retrovirus of chicken that encodes for a fusion protein, P68 ${ }^{g a g-R O S}$, having tyrosine specific kinase activity. ${ }^{14}$ The oncogene, v-ROS, of UR2 carries a kinase domain that is homologous to those present in the oncogenes of the src family. ${ }^{15}$ The c-ROS sequence appeared to be conserved in vertebrate 
species, from fish to mammals, including humans. ${ }^{13}$ The comparison of the deduced amino acid sequence of c-ROS and that of v-ROS showed two differences; 1) v-ROS contains a three amino acids insertion within the hydrophobic domain (TM domain), presumed to be involved in membrane association, 2) The carboxyl 12 amino acids of v-ROS are completely different from those of the deduced c-ROS sequence. ${ }^{12}$

Early reports have indicated that the deduced amino acid sequence of the kinase domain of ROS is highly homologous to that of the kinase domain of the human insulin receptor (HIR). ${ }^{12,16}$ However, it was proved later on, that the amino acid sequences in the kinase domains of these two RTKs are highly different. The homology level in the amino acid sequence in the kinase domains of ROS and HIR was found to be only $48.5 \%{ }^{13}$ On the other hand, the overall structure of c-ROS gene showed that the encoded protein carries an extracellular domain with a potential site of $N$-linked glycosidation, a hydrophobic 24-amino acids stretch, and a tyrosine kinase domain. ${ }^{13}$ These structural organizations are similar to those of the c-ErbB (the gene of the epidermal growth factor receptor), the cFms (the gene of macrophage colony-stimulating factor receptor) and the HIR gene. ${ }^{14,17-19}$ These results strongly suggested that the human ROS gene encodes for a trans-membrane molecule which may function as a receptor for cell growth or differentiation factors. The analysis of c-ROS gene sequence applied to a transcript separated from rat lung, ${ }^{20}$ and later on, for a cDNA from the human glioblastoma cell line, AW-1088, ${ }^{21}$ indicated a homology between the putative extracellular domain of ROS and the extracellular domain of the sevenless gene product of Drosophila melanogaster. Sevenless is a gene required for normal eye development in the fruit fly Drosophila melanogaster and it also encodes a transmembrane tyrosine specific protein kinase. ${ }^{22,23}$ The c-ROS oncogene was proved to be a member of the src gene family, ${ }^{24}$ the proteins encoded by these genes have a high degree of amino acid sequence homology and are all associated with tyrosine specific kinase activities. ${ }^{25}$

\section{3. c-ROS GENE DISTRIBUTION AND FUNCTION}

The trans-membrane RTK ROS shows a specific profile of expression restricted primarily to distinct epithelial cells during embryonic development. ${ }^{26-29}$ When c-ROS was first isolated from the chicken genome, tissues at various stages of chicken development were analyzed, but only kidneys were found to contain a significant level of c-ROS

DNA. ${ }^{12}$ Shortly after the first isolation of c-ROS from chicken, the expression of c-ROS gene in rats was examined

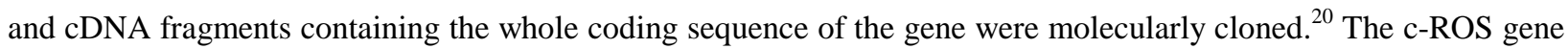


was found to be expressed in a tissue specific manner with c-ROS transcripts of varying sizes in different tissues. The obtained transcripts were isolated from lungs, kidneys, heart and testis. ${ }^{20}$

The in vivo expression pattern of ROS in mice was also determined, where transient ROS expression was found during development, in kidneys, lungs and intestine. ${ }^{26}$ It was found also that ROS mRNA is present in the caput segment of the epididymis of adult mice. ${ }^{27}$ The expression was found to be restricted to the epithelial cells of the epididymis and is initially detected at the onset of regionalization of the caput epididymis. ${ }^{27}$ In humans, ROS was found to be expressed throughout the human epididymis at varying levels, while absent from the proximal caput. ${ }^{30} \mathrm{~A}$ recent northern blot analysis of RNA isolated from various adult human organs has determined that the highest ROS expression was detected in the lungs. Size variants were also detected in RNA isolated from placenta and skeletal muscle tissues. ${ }^{6}$

The expression pattern of ROS in different organs suggests that it may play a role in the mature functions of these organs beyond the developmental role. It's important also to notice that usually cellular homologues to retroviral transforming genes play an important role in cellular growth and/or differentiation, and appear to have oncogenic potential that can be manifested after transduction by a retrovirus. The process of conversion from a normal proto-oncogene to a transforming oncogene involves either mutation and/or degradation. ${ }^{17,25,31,32}$

\section{ONCOGENIC EXPRESSION OF ROS}

The human c-ROS gene was mapped to the human chromosome 6 region 6q166q22 . ${ }^{33}$ This region of chromosome 6 is involved in non-random chromosomal rearrangement in specific neoplasias, including acute lymphoplastic leukemia, ${ }^{34}$ malignant melanoma, ${ }^{35}$ and ovarian carcinomas. $^{36}$ c-ROS gene up-regulation and/or mutation were found mainly in brain and lung cancers, in addition to chemical-induced stomach cancer, breast fibroadenomas, liver, colon and kidney cancers.

\subsection{ROS in brain tumors}

A number of RTKs are characteristic as markers for nervous system tumors. In particular, the epidermal growth factor receptor (EGFR) and its associated oncogene Erb-B are noteworthy, since 45-50\% of malignant gliomas show evidence for EGFR amplification. ${ }^{37-40}$ Other RTKs include Neu, ${ }^{41-44}$ platelet derived growth factor (PDGF) receptor $^{45-48}$ and $\operatorname{ROS}^{49-52}$. In a survey of 45 different human cell lines, ROS was found to be expressed in $56 \%$ of 
glioblastoma derived cell lines at high levels (ranging from 10 to 60 transcripts per cell), while not expressed at all or expressed minimally in the remaining cell lines. ${ }^{49}$ Moreover, no expression of ROS gene was observed in normal brain tissues, thus, the high level of ROS expression in glioblastoma seems specific.

In all of the tested glioblastoma cell lines, the c-ROS encoded transcript was found to be $8.3 \mathrm{~Kb}$ in size, except for the cell line U-118MG, where its size was found to be only $4 \mathrm{~Kb}$, which suggests that the glioblastoma cell line U-118MG produces a high level of an altered (mutated) ROS-encoded protein. These results were contradicted by the findings of $\mathrm{Wu}$ and Chikaraishi ${ }^{53}$ where they failed to detect elevated ROS expression in a survey of 25 specimens taken from patients with astrocytomas and glioblastoma multiformes (GBM) of all histological grades. However, they did not rule out the possibility of presence of small clones in the tumor, in which ROS is expressed in significant levels, but diluted with the larger population of non-ROS or low-ROS expressing cells. They expected also that ROS expression could be induced when the astrocytomas or glioblastomas were adapted in tissue culture.

However, the over-expression of ROS in surgical specimens was proved later by two independent analyses using RNase protection and cDNA hybridization techniques, where high levels of ROS expression in $33 \%$ and $40 \%$ of glioblastoma surgical tumors has been reported. ${ }^{50,51}$ The failure of ROS detection in lower grade astrocytomas suggests however that ROS may play a role in tumor progression rather than initiation. ${ }^{50}$ The expression of ROS in meningiomas was also evaluated by complete reverse transcription and polymerase chain reaction (RT-PCR) assays. ${ }^{54}$ ROS was found to be expressed at high levels in meningiomas (55\%, 17 of 33) while not expressed in nonneoplastic brain samples. Recently, the expression of ROS in malignant glioma tumors was also evaluated. ${ }^{52}$ ROS was found to be over-expressed in $25 \%$ of low grade and $30 \%$ of malignant gliomas. From a total of 231 astrocytic glioma samples, it was found that 23\% (11 of 47) of grade II, 17\% (13 of 78) of grade III and 29\% (31 of 106) of glioblastoma multiformes expressed ROS.

\subsection{ROS in non-small cell lung cancer (NSCLC)}

In a large scale survey of tyrosine kinase activity in lung cancer, tyrosine kinase signaling was characterized across 41 NSCLC cell lines and over 150 NSCLC tumors. ${ }^{55}$ Profiles of phosphotyrosine signaling were generated and analyzed to identify known oncogenic kinases. Surprisingly, ROS kinase was of the top ten RTKs found in both cell lines and tumors. RTKs in this survey were ranked according to phosphorylation rank (phosphorylation level/sample). The results revealed that ROS kinase was highly expressed in one tumor sample and in the NSCLC 
cell line (HCC78). ${ }^{55}$ In addition to ROS over-expression in these samples, PTPN11 (protein tyrosine phosphatase, non-receptor type 11) and IRS-2 (Insulin receptor substrate-2) previously reported to be important downstream effectors of ROS in glioblastoma ${ }^{56}$ were found to be highly phosphorylated in ROS expressing samples. ${ }^{55}$

Furthermore, several microarray analyses of tumor specimens revealed significantly elevated ROS expression levels in $20-30 \%$ of patients with NSCLC. ${ }^{57-59}$ Contrasting for brain tumors, elevated ROS expression in lung tumors was observed in both early and late stage tumors, ${ }^{60}$ suggesting a key role for ROS in the initiation or development rather than progression of lung tumors.

\subsection{ROS in stomach, breast, liver, colon and kidney cancers}

c-ROS gene was found to be up-regulated in gastric cancer induced by oral administration of $N$-methyl- $N$ '-nitro- $N$ nitrosoguanidine (MNNG) in rat. ${ }^{61}$ ROS gene was one of six genes found to be persistently up-regulated after 4 weeks from MNNG treatment. ROS gene was found also to be over-expressed (in a number of other genes) in fibroadenoma samples taken from breast tumors of 5 different patients. It was found to be expressed at levels more than 2 fold higher than those in normal tissues. ${ }^{62}$

In liver, the induction of hepatic progenitor cells activation in a rat model of liver injury was found to be associated with over-expression of ROS. In addition, over-expression of ROS was also observed in a rat hepatoma

cell line. ${ }^{63,64}$ Recently, a global sequencing survey of all tyrosine kinases in 254 cell lines revealed three new ROS mutations in two colon adenocarcinoma and one kidney carcinoma cell lines. ${ }^{65}$

\section{MUTANT FORMS OF ROS}

The most common methods for RTKs activation in cancer cells are genomic arrangements, exemplified by gene amplifications, chromosomal translocations, inversions and deletions. ${ }^{2}$ Many of these genomic aberrations have been shown to results in the formation of onco-fusion proteins. Similarly, five different onco-fusion ROS proteins have been identified and characterized so far, these fusions are v-ROS, Mcf3, FIG-ROS, SLC34A2-ROS and CD74ROS.

\section{1. v-ROS and Mcf3}


The transforming gene product, P68 ${ }^{g a g-R O S}$, encoded by UR2 sarcoma virus genome is a rearranged product of the chicken c-ROS gene. ${ }^{12}$ Studies made on v-ROS have revealed that the 3 '-change of v-ROS has little effect on activation of the transforming potential of c-ROS, while 5'-truncation (deleting all but 6 amino acids of the extracellular domain) and fusion to gag are required for activation of c-ROS transforming activity, although this activity is not as potent as that of v-ROS. ${ }^{66}$ Combination of 5 '-truncation and the 3 amino acids insertion in the TM domain is sufficient to convert c-ROS into an oncogene as potent as v-ROS. ${ }^{66}$

To further explore the role of this 3 amino acids insertion in v-ROS, this sequence was deleted and the transforming function and signal transduction of the mutant protein were investigated. ${ }^{67}$ The obtained results revealed that the three amino acids deletion has no effect on the protein tyrosine activity of v-ROS, but this deletion results greatly in reduced transforming and mitogenic potency, as well as an altered protein modification and substrate interaction, despite the fact that the cytoplasmic domain of the mutant protein is unaltered. ${ }^{67}$

In mammalian species, an activated form of human c-ROS gene, $M c f 3$, has been isolated from the DNA of the human carcinoma cell line MCF-7, using a tumorigenicity assay. ${ }^{68,69}$ Mcf3 probably arose during gene transfer from a normal human c-ROS gene, by the loss of a putative extracellular domain. In this transformation, all of the amino acids (except only 8) of the putative extracellular domain of c-ROS are thought to be replaced by another unknown piece of DNA. ${ }^{69}$ The point of fusion between cellular and viral sequences in v-ROS gene was found to be located in an analogous position to that in $M c f 3$ fusion, leading to the loss of most of the putative extracellular domain. ${ }^{12}$ Accordingly, the deletion of the extracellular domain appears to be an important event in the activation of the oncogenic potential of the c-ROS gene.

\subsection{FIG-ROS}

Elevated expression of growth factors and/or their related tyrosine kinase receptors has been found in all grades of

astrocytomas. ${ }^{39,70-73}$ In most of the cases analyzed, this increased expression is the result of a gene amplification. The first genomic rearrangement reported in astrocytomas that results in the creation of a fusion RTK protein is 'FIGROS' fusion. This genomic fusion was noticed for the first time in the survey carried out by Birchmeier et al., ${ }^{49}$ on glioblastoma-derived cell lines, where a common transcript of $8.3 \mathrm{~Kb}$ was separated from all over-expressing glioblastoma cell lines except U-118MG, where a shorter transcript of only 4 Kb was observed. 
The point of divergence between the normal and U-118MG c-ROS genes was located to that portion of c-ROS that encodes the junction between the putative extracellular and trans-membrane domains (TM domain). ${ }^{49}$ Interestingly, this point of rearrangement in U-118MG DNA was found to be very close to the point of rearrangement that created v-ROS and Mcf3 genes. ${ }^{15}$ After about 15 years, the molecular details for this genetic transformation have been explored by Charest $e t$ al. ${ }^{74,75}$ They demonstrated that an intra-chromosomal homozygous deletion of $240 \mathrm{kDa}$ on 6q21 is responsible for the formation of FIG-ROS transcript. FIG (Fused in Glioblastoma) is a gene that encodes a protein that peripherally associates with Golgi apparatus, and likely plays a role in Golgi function. ${ }^{76}$ This FIG-ROS transcript is encoded by 7 FIG exons, and 9 ROS derived-exons, and is a constitutively active fusion protein (Fig. 1).

\section{Figure 1}

This was the first example for a fusion RTK protein that resulted from an intra-chromosomal deletion, and it represents the first fusion RTK protein isolated from a human astrocytoma. In order to ascertain the frequency of FIG-ROS fusion event in glioblastoma, 10 different cell lines derived from all grades of astrocytomas were screened for the presence of FIG-ROS. Two GBM cell lines (U-118MG and U-138MG) have showed expression of FIG-ROS locus, ${ }^{75}$ and an identical breakpoint was found in the FIG-ROS transcripts taken from both of these two cell lines. These two cell lines were established concurrently from the same patient, ${ }^{77}$ strongly suggesting that the deletion was present in the primary tumor before the establishment of these two cell lines in culture, and is less likely to represent a culture artifact.

It has been reported that FIG peripherally associates with Golgi apparatus through its second coiled coil. ${ }^{76}$ This portion is retained within FIG-ROS fusion, suggesting that it may also target the Golgi apparatus, and this targeting would be sufficient to incur an activation of its tyrosine kinase domain. ${ }^{75}$ These results have demonstrated that the FIG-ROS locus encodes for an in-frame fusion protein with a constitutive kinase activity, suggesting that FIG-ROS may act as an oncogene. A recent study has further proved the oncogenic potential of FIG-ROS through the in vivo induction of glioblastoma formation in CNS, in a genetically engineered mouse model of brain cancer. ${ }^{56}$

\subsection{SLC34A2-ROS and CD74-ROS}


Relative to other cancer types, only a limited number of gene translocations and mutant proteins have been reported in lung cancer, such as the $\mathrm{t}(15 ; 19)$ translocation involving notch3. ${ }^{78} \mathrm{~A}$ transforming fusion gene "EML4-ALK" has been recently identified by Soda et al. ${ }^{79}$ in $6.7 \%$ of smoker Japanese patients with non-small cell lung cancer. This chimeric gene which was generated by a small inversion within the chromosome 2 short arm encodes a 1059 amino acids fusion protein. ${ }^{80}$ However, the first reported translocations in human NSCLC involving protein kinases were those of ROS. ${ }^{55,81,82}$ The first translocation, SLC34A2-ROS, resulted from the fusion of c-ROS to the transmembrane solute carrier protein (SLC34A2) was discovered in the NSCLC cell line HCC78. ${ }^{55,81}$ This translocation between chromosomes 4q15 and 6q22 produced two fusion protein variants, that combine the $\mathrm{N}$ terminus of sodium-dependent phosphate transporter protein, with the transmembrane and kinase domains of the proto-oncogene RTK ROS (Fig. 2A). The resulting SLC34A2-ROS fusion proteins, which are 724 amino acids (long variant) and 621 amino acids (short variant) are expected to retain kinase activity, and to derive the proliferation and survival of a subset of human NSCLC tumors, in which the fusion protein is expressed.

SLC34A2 is a phosphate transporter protein that is expressed in human lung and small intestine, and which has Na-dependent activity. ${ }^{83}$ Defects in SLC34A2 expression and/or activity have been previously reported in ovarian cancer. ${ }^{84}$ In order to verify the role of this genetic fusion in the initiation and development of the cancerous cells harboring it, the ability of two different siRNAs, targeted against c-ROS, to inhibit HCC78 cellular growth was evaluated. ${ }^{55}$ Both of the two tried siRNAs were found to be effective in reducing ROS protein expression, and inducing cell death in HCC78 cells, demonstrating a strict dependence on ROS signaling for HCC78 cells survival.

\section{Figure 2}

The second ROS fusion (CD74-ROS) was identified in a c-ROS positive NSCLC tumor, where a translocation between chromosomes 5q32 and 6q22 resulting in the fusion of the $N$-terminus of CD74 to ROS at the typical site of the short transcript of SLC34A2-ROS fusion created a fusion protein (703 amino acids length) with two transmembrane domains, as in SLC34A2-ROS fusion, (Fig. 2B). ${ }^{55,82}$ CD74 is a type II trans-membrane protein that functions as the receptor for the macrophage migration inhibitory factor (MIF) immune cytokine. ${ }^{85}$ CD74 functions also as an MHC (major histo-compatibility complex) class II chaperone protein which plays a critical role during peptide presentation to CD4-positive lymphocytes. ${ }^{86}$ 


\section{ROS SIGNALING}

It has been demonstrated by the limited number of studies made on ROS kinase, that ROS activates several signaling pathways important for cell growth and survival. However, this kind of studies about ROS signaling is so limited, because of lack of knowledge about ROS ligand. To date, it was found that ROS activation involves these downstream activators and effectors:

\subsection{STAT3}

Signal transducers and activators of transcription (STATs) are transcription factors that regulate many aspects of cell growth, survival and differentiation. They are involved in cytokine and growth factor receptor induced gene expression. These transcription factors are activated by tyrosine phosphorylation, and they were found to be activated in a number of primary tumors, leading to increased angiogenesis, enhanced survival of tumors and immuno-suppression. ${ }^{88,89}$ The seven mammalian STAT family members identified so far are STAT1, STAT2, STAT3, STAT4, STAT5 (STAT5A and STAT5B), and STAT6. It's noteworthy to mention that the constitutive activation of STAT3 has been reported in malignant brain tumors, ${ }^{90}$ and that STAT3 activation has been associated with resistance to chemo- and radiotherapy, which is a characteristic feature in CNS cancers. It has been also reported that ROS activates predominantly STAT3 in NIH-3T3 cells, and that STAT3 is required for ROSanchorage-independent growth. ${ }^{91}$ Accordingly, the activated function of STAT3 seems to be important for the establishment and maintenance of ROS-induced cell transformation.

\subsection{VAV3}

VAV proteins are guanine-nucleotide exchange factors for Rho GTPases that regulate actin dynamics and gene expression. Three VAV members have been identified, Cel-VAV ${ }^{92}$ and two mammalian VAVs (VAV2 and VAV3). ${ }^{93,94}$ Although all VAV family proteins have similar structural features, they display different tissue expression patterns. VAV is primarily expressed in hematopoietic lineages, while VAV2 is ubiquitously expressed. ${ }^{95,96}$ VAV3 has a broad but different expression profile compared to that of VAV2. ${ }^{97,98}$ It has been reported that stimulation of several RTKs, including ROS, leads to tyrosine phosphorylation of VAV3 as well as its interaction with the receptor protein and its downstream signaling molecules. ${ }^{99}$ ROS-VAV3 interaction was found to 
be constitutive and independent of ROS activation. The inhibition of VAV/Rho GTPase signaling was found to be successful in suppressing ROS-induced colony formation in chicken embryo fibroblasts (CEFs) and anchorageindependent growth in NIH-3T3 cells. ${ }^{100}$

\subsection{PI3K/AKT/m-TOR signaling cascade}

The Phosphoinositide-3 kinase (PI3K) signaling pathway is a key regulator in a number of cellular processes, such as cellular proliferation, differentiation and apoptosis. ${ }^{101,102}$ The AKT kinase, is a major downstream target of PI3K, and is an important mediator in cell growth and function. ${ }^{103,104}$ The activation of PI3K/AKT pathway was found to be an important event for ROS-induced transformation, and the inhibition of PI3K signaling pathway was proved to significantly diminish the ability of ROS to induce colony formation and anchorage-independent growth of fibroblasts. ${ }^{100,105}$ The activation of PI3K by ROS is thought to be mediated by IRS-1 scaffold protein, since the activity of PI3K was significantly decreased using SIR-1 antibodies. ${ }^{105,106}$

It has been demonstrated also that FIG-ROS can activate the PI3K/AKT/m-TOR signaling pathway in FIG-ROS induced-brain tumor. ${ }^{56}$ In addition, the m-TOR inhibitor, rapamycin, ${ }^{107}$ was capable of inducing dose dependent growth inhibition in FIG-ROS brain tumor cell cultures, ${ }^{56}$ which suggests that m-TOR inhibitors may be effective in treating ROS-activated malignancies.

\subsection{SHP-1}

The SH2-domain containing protein tyrosine phosphatase SHP-1, ${ }^{108,109}$ is expressed in hematopoietic, and at lower levels, in epithelial cells. It has been speculated that the defects in sperm maturation in ROS ${ }^{-/}$mice (with a targeted mutation of c-ROS) ${ }^{27}$ and me ${ }^{v}$ mice (with $80-90 \%$ reduction of SHP-1 activity) ${ }^{110}$ might be related at the molecular level. This speculation was based on the hypothesis that, if ROS and SHP-1 interact in a common signal transduction pathway, impairment of the epidermal function might result from inactivation of either gene. Indeed, the molecular analysis has revealed that ROS binds and activates SHP-1 and that SHP-1 strongly binds ROS, and regulates ROS signaling in a negative manner, through a -ve feed back inhibitory mechanism. ${ }^{111}$ ROS and SHP-1 are co-expressed in epididymal epithelium, and elevated phosphorylation of ROS in the epididymis of me ${ }^{v}$ mice suggests that ROS signaling is under control of SHP-1 in vivo. The interaction between SHP-1 and ROS was found to be mediated by high affinity binding of the SHP-1 $N$-terminal SH2 domain, and ROS phosphopeptides binding 
sites pY2267 and pY2327. ${ }^{112}$ These two phosphopeptides binding sites were found to be differentially employed in binding to SHP-1, where pY2267 was found to be involved in ligand-dependent stimulation of complex formation, while pY2327 mediates constitutive ligand-independent SHP-1 association. ${ }^{112}$

A number of linear and cyclic phosphopeptides related to the pY2267 binding site of ROS kinase have been synthesized and evaluated as ligands for the amino terminal SH2 domain of the protein tyrosine phosphatase SHP-1, in order to be used as activators for ROS down-regulation. ${ }^{113,114}$ The synthesized derivatives displayed much lower potencies for the stimulation of SHP-1 activity, but higher affinities relative to ROS pY2267, recommending their use as SHP-1 competitive inhibitors rather than agonists for phosphatase activity. ${ }^{114}$

\subsection{SHP-2}

In addition to binding to SHP-1, ROS kinase was found to bind and activate the SH2-domain containing protein tyrosine phosphatae SHP-2. ${ }^{56}$ PTPN11, the gene encoding for SHP-2, was found to be mutated in a number of hematological malignancies, ${ }^{115-117}$ and solid tumors. ${ }^{118}$ The constitutively active SHP-2 is hence considered to be an oncogene, and the source of its oncogenicity comes from its ability to regulate the activation of a number of RTKs to the RAS/Raf/MEK/ERK signaling cascade. ${ }^{119-121}$ It was found also that the oncogenic activity of FIG-ROS fusion protein is mediated through phosphorylation of SHP-2, suggesting that SHP-2 activation is a crucial event in FIGROS transformation. ${ }^{56}$ Furthermore, in SLC34A2-ROS and CD74-ROS fusion proteins harboring cells, the phosphopeptides corresponding to the tyrosyl phosphorylation sites of SHP-2 were found to be up-regulated. ${ }^{55}$ These results strongly suggest that the activation of SHP-2 tyrosine phosphatase is an important signaling mediator for the constitutive activity of ROS kinase.

\section{7. c-ROS: A GENETIC VARIANT FOR CARDIOVASCULAR (CV) DISEASES}

As mentioned before, the physiological roles of c-ROS gene expression in different body organs have not been fully characterized. However, a number of studies have correlated between c-ROS and the incidence of different cardiovascular diseases. A large-scale, gene-centric association study made on 11,053 single nucleotide polymorphisms (SNPs) from 6891 genes has suggested that the risk of myocardial infarction (MI) was associated with specific genes, so far not linked to atherosclerosis. ${ }^{122}$ These genes encode the cytoskeletal protein paladin (PALLD), a taste receptor (TAS2R50), an olfactory receptor (OR13G1), a zinc finger protein (ZNF627) and ROS. 
However, a number of subsequent studies failed to prove such association between MI and these genetic variants, ${ }^{123-}$ 125 emphasizing the high potential of false positive results obtained from the initial study, and indicating the necessity for continued refinement of cardiovascular genetic methodologies for clinical applications.

In two other studies applied to Japanese individuals, links have been proposed between the polymorphism of cROS gene (in a number of other genes) and restenosis ${ }^{126}$ and hypertension. ${ }^{127}$ In the first study, polymorphism of BCHE, GPX1 and c-ROS genes were found to be independently associated with in-stent restenosis after bare-metal stenting of coronary arteries, suggesting a genetic risk of these gene-determinants in in-stent restenosis. ${ }^{126}$ In the second study, polymorphism in ABCA1 and c-ROS genes were reported in hypertensive Japanese patients, suggesting the possibility of using these genotypes for the prediction of the genetic risk for hypertension. ${ }^{127}$ The genetic risk of atherothrombotic cerebral infarction was also correlated to c-ROS gene polymorphism, where in two

different studies, ${ }^{128,129}$ c-ROS gene was among a number of other genes whose polymorphism was proposed to be informative for the prediction of the genetic risk of atherothrombotic cerebral infarction.

These frequent observations of c-ROS gene in a number of different CV diseases, and in every time among a number of varying genes, suggest a real possible role for ROS in one or more of these CV diseases. Furthermore, the reasonable expression of ROS reported in heart ${ }^{20}$ and epithelial tissues ${ }^{26-29}$ provides another reason for considering a role of this gene in the CV system. However, the lack of ROS-ligand identity is a key difficulty in the full understanding of its role in different body tissues, and the identification of such ligand may provide important answers for such questions.

\section{8. c-ROS GENE AND INFERTILITY}

Transgenic mice targeted for c-ROS gene are fertile when heterozygous (HET) but infertile when homozygous (Knockout, KO). ${ }^{27,130}$ The infertility of male homozygous c-ROS knockout mice, inspite of normal mating contrasts with the effectiveness of cauda epididymal sperm in fertilizing ova in vitro, ${ }^{27}$ and the most obvious explanation of these results would be that the motility of sperms from the knockout animals is impaired, so that they fail to reach the oocytes in vivo. ${ }^{131}$ c-ROS knockout mice lack the prepubertal differentiation of the epididymal initial segment, and a high proportion of sperms released from the cauda epididymis of these mice display sever tail angulations at the midpiece. ${ }^{130}$ These flagellar angulations were thought to be the reason behind the reduced sperm numbers in the oviduct of mated females, and the failure to fertilize in vivo. ${ }^{130}$ 
However, because the majority but not all the mature epididymal sperms from the knockout mice exhibit tail angulations, these findings suggest the possibility of some motile sperms with straight tails migrating into the oviduct, so the complete infertility of knockout males remain unexplained. One crucial aspect of natural fertilization is the binding of sperms to the oviductal epithelium for survival and prevention of precocious capacitation. ${ }^{132-137}$ Because the initial epididymal segment is active in the synthesis of specific epididymal secretions, and this segment fails to differentiate in the sterile c-ROS knockout males, it is possible that sperms from these males are not normally endowed and consequently incapable of normal interaction with the oviductal epithelium and fail to reach the oocyte in a potentially fertilizing state. ${ }^{131}$

Hence, the infertility of c-ROS knockout male mice can be explained by the inability of sperms to enter the oviduct, as a result of the bent tails of the majority of them compromised by their inability to effectively interact with the oviductal epithelium. Because flagellar angulations usually reflect a defect in volume regulation, ${ }^{130,138}$ and the capacity for sperm volume regulation is developed during maturation in the epididymis, ${ }^{139}$ it was important to verify modifications in luminal fluid of c-ROS knockout male mice. A number of studies have revealed variable changes and abnormalities in the luminal fluid of these mice. ${ }^{140-142}$ It was found that c-ROS homozygous knockout mice don't express the glutamate transporter excitatory amino acid carrier 1 (EAA1) mRNA in the caput, and since glutamate is used as a an osmolyte in somatic cells, the lack of EAA1 may disrupt osmolyte balance in the proximal epididymal lumen, affecting sperm maturation and the development of sperm volume regulatory mechanisms. ${ }^{140} \mathrm{~A}$ decrease in the Na-hydrogen exchanger NHE2 in the caput, and NHE3 in the cauda, associated with increase in luminal fluid $\mathrm{pH}$ in the c-ROS knockout male mice was also reported. ${ }^{141}$ In another study, an increased $\mathrm{K}^{+}$ion concentration in cauda epididymal fluid was observed. ${ }^{142}$ These abnormal changes in sperm content which result in maturational abnormalities in volume regulation might have a compromising effect to sperm tail angulations, leading finally to c-ROS knockout male mice sterility.

The much concern about c-ROS gene and its role in the infertility of c-ROS knockout mice suggests the possibility of future using of ROS inhibitors as male contraceptives. However, a number of important points should be considered. First of all, the distinct differences between the human and mice epididymis, and the corresponding variations in ROS expression pattern in the epididymis of each of them may lead to a different effect of ROS inhibition in humans, which is not necessarily a complete infertility. The other important point to be considered is that the changes in the sperms of c-ROS knockout mice which made them to be infertile are thought to be caused by 
maturational defects in the epididymis before puberty. Hence, the effect of ROS-inhibition on the fertility of mature wild male mice, and consequently on adult humans, would likely be significantly different.

\section{ROS-INHIBITION FOR CANCER TREATMENT}

It could be concluded from what is described in the previous sections that ROS kinase (with its fusion forms) is an important deriver for a number of cancers, and that the targeting and inhibition of its activity could provide more efficient and selective solutions for the treatment of substantial cancers derived by it. The ability to diagnose and identify the cancer types harboring c-ROS mutations is as important as the development of selective and potent inhibitors for ROS RTK. The ability to identify, as early as possible, cancers that are derived by a mutant ROS kinase will greatly assist in determining the suitable therapeutic, or combination of therapeutics, that is most appropriate for the patient, thus helping to avoid description of inhibitors targeting other kinases that are not, in fact, the primary signaling molecule deriving the cancer.

For example; although targeted EGFR inhibitors are currently approved for the treatment of NSCLS, ${ }^{87}$ it's anticipated that this therapy might be partially or wholly ineffective against those patients having tumors in which, mutant ROS kinase (rather than or in addition to EGFR) is expressed and deriving the disease in whole or in part. Instead, these tumors are most likely to respond to inhibitors for the mutated ROS kinase.

Moreover; a recent discovery has proved a high potential risk if the demethylating agent, 5-aza-2'-deoxycitidine (5-aza-dc) used for the treatment of ROS-derived tumors, since the ectopic expression of c-ROS in tumors was found to be tied to hypomethylation of a CPG island in the c-ROS promoter region, which means that ROS expression could be further activated by treatment of c-ROS negative cells with the demethylating agent (5-azadc). ${ }^{52}$

In this stream, new sensitive and selective probes for the detection of SLC34A2-ROS and CD74-ROS fusions

have been patented recently. ${ }^{81,82}$ Furthermore, a reporter construct that recognizes the phosphorylated state of c-ROS has been also recently engineered. ${ }^{143}$ This new construct recognizes c-ROS activity and tests the ability of any potential inhibitor to turn-off ROS kinase activity. The construct is made of six parts, cyan fluorescent protein (CFP), a ROS substrate domain, a flexible linker, a recognition domain for tyrosine phosphorylation, a yellow fluorescent protein (YFP) and a nuclear export sequence. The construct changes conformation when ROS 
phosphorylates the substrate domain, and this alteration can be recognized by measuring the fluorescence resonance energy transfer (FRET) between the CFP and YFP fluorophores.

\section{ROS INHIBITORS AND POTENTIAL USES}

The discovery of selective ROS kinase inhibitors was an important step to verify a number of theoretical speculations about ROS, and also to test for the applicability of these inhibitors in the clinical uses presumed for ROS inhibitors. Since the approval of the first kinase inhibitor, Gleevec, ${ }^{5}$ for treatment of chronic myeloid leukemia, a vast growth has been noticed in the field of drug discovery for the development of new selective kinase inhibitors targeted against mutant kinases. A number of inhibitors such as Staurosporine, AST-487 and PP 2 have been reported to inhibit ROS kinase, and even with high potency in some of them (as in case of Staurosporine, $\mathrm{IC}_{50}=0.9$ $\mathrm{nM}$ ), but all these inhibitors were unfortunately highly unselective (Fig. 3). ${ }^{144}$ The lack of selectivity in these inhibitors prohibited their clinical uses against any of the kinases inhibited by them in most of the cases (Table I). ${ }^{145}$

Figure 3

\section{Table I}

\subsection{Recent discovery of selective and potent ROS kinase inhibitors}

The first selective and potent ROS kinase inhibitors have been recently developed by our group.,8 A new hit pyrazole derivative (KIST301072) was discovered during screening of new potential kinase inhibitors prepared in our laboratory over a large panel of kinases (Fig. 3). KIST301072 was initially screened over a panel of 45 different kinases at a single dose concentration of $10 \mu \mathrm{M}$. At this concentration, a 94\% inhibition of the enzymatic activity of ROS kinase was observed, while the inhibition in activity was below 30\% in all of the other kinases. ${ }^{7}$ The compound was then further tested in a 10-dose $\mathrm{IC}_{50}$ mode and showed an $\mathrm{IC}_{50}$ value of $199 \mathrm{nM}$ for ROS kinase (Table II).

Table II 
Following the discovery of this compound, we have synthesized a series of structurally related compounds and evaluated their capacity to inhibit ROS kinase. ${ }^{8}$ A new equipotent structurally simplified hit was evolved in this study, where KIST301080 showed in Fig. (3) was found to inhibit ROS kinase activity with an IC $_{50}$ value of 209 nM.

\subsection{Potential clinical applications of ROS kinase inhibitors}

As showed in table III; a number of potential clinical applications and uses are speculated for ROS kinase inhibitors. At the top of these applications is the ability of these inhibitors to treat and inhibit tumors derived by ROS kinase. Accordingly; it is very important now to evaluate the ability of these inhibitors to inhibit the growth of cancer celllines that are over-expressing c-ROS or harboring ROS mutations, such as GBM U-118MG and NSCLC HCC78 cell lines. Generally, it is anticipated that compounds which can inhibit the activity of wild ROS would be also capable of inhibiting mutant forms of ROS, since the kinase domain is conserved in all ROS-fusion proteins, and the transformations in such mutants involve only the extracellular domain. The inhibitors could be also tested in vivo by evaluating their ability to inhibit the growth of engineered tumors derived by ROS mutations, like the previously reported FIG-ROS induced brain cancer. ${ }^{56}$ The selective responsiveness of cells bearing ROS mutations to these inhibitors would provide a new and feasible tool for the identification of cancers that are derived by ROS, by simply evaluating the inhibitory effect of these inhibitors over a large panel of suspected cell lines.

It would be also interesting to use these inhibitors to test for the sensitivity and applicability of the newly engineered reporter construct designed to test for the ability of potential inhibitors to turn-off ROS kinase activity. ${ }^{143}$ The emergence of these new potent and selective inhibitors could also open the way for the verification of the ability of ROS inhibitors to be used as male contraceptives. The treatment of wild adult mice with ROS inhibitors and evaluating the ability of the inhibitors to produce infertility temporarily would be of great impact on the field of development of male contraceptives. Similarly, the doubt about a genetic role for ROS in a number of cardiovascular diseases could be also verified by testing the capability of ROS inhibitors to reverse and cure such diseases.

Table III 


\section{OTHER METHODS FOR ROS INHIBITION}

In addition to small molecular kinase inhibitors, the inhibition of ROS kinase could be achieved by some other alternative ways. These alternatives include the use of ROS-kinase targeted antibodies that specifically bind to critically catalytic or binding domains required for ROS activity, and inhibit the kinase by blocking access of ligands, substrates or secondary molecules. It's important however to note that the use of antibodies that target the extracellular domain of ROS would be useless in inhibiting mutant ROS-fusion proteins, since in these fusion proteins the extracellular domain is totally or partly lost. Instead, the antibodies targeting the newly fused part (from FIG, SLC34A2 or CD74 for example) could be helpful in inhibiting the activity of these fusion proteins.

Another possible alternative is the use of small interfering RNA (siRNA), which inhibits gene translation and hence activity of ROS kinase, through the process of RNA interference. RNA interference and selective silencing of target protein expression by introduction of exogenous small double strand RNA molecules comprising sequence complementary to mRNA encoding the target protein has been well described. ${ }^{146-150}$ The use of siRNA against ROS has been already proved to be effective in ceasing ROS expression and inducing cell death in HCC78 NSCLC cells, ${ }^{55}$ as previously described in this review. The inhibition of ROS signaling could be also achieved by indirect ways, through the interference with its downstream effectors, such as STAT3, VAV3, SHP-1, SHP-2, and

PI3K/AKT/mTOR signaling mediators. As mentioned previously, the inhibitions of m-TOR ${ }^{56}$ and VAV/Rho GTPase signaling ${ }^{100}$ were successful in suppressing ROS signals and subsequently inhibiting ROS-induced cell growth. Accordingly, the inhibitors for such signaling downstream effectors could be useful, alone or in combination with specific ROS inhibitors, for the silencing of amplified c-ROS signaling in different diseases.

\section{CONCLUSION}

The discovery of c-ROS gene along with the subsequent discovery of its ectopic expression in different types of cancer, and the recent discovery of its mutant forms have shed light on its importance as a new potential target for treatment of cancer. The possible relation between c-ROS genetic alleles and the incidence of different cardiovascular diseases raises a question about possible roles for this gene in diseases other than cancer. The full distribution and expression profiles for ROS in different body organs and its physiological roles in normal body functions as well as in diseases needs to be further explored. The absence of any useful information about the activating ligand of ROS is a big mystery that awaits to be solved. The possibility of presence of more than one 
ligand that is involved in different functions cannot be omitted. The recent discovery of ROS selective inhibitors should however help in providing useful answers for a number of questions; the majority of which are about the applicability of using ROS inhibitors in treatment of ROS derived cancers, as well as in other speculated applications, such as male contraception. During the next few years, the success in optimizing a more potent and selective ROS kinase inhibitor with good pharmacokinetic profile, can raise the interest about ROS kinase and attract the attention of researchers from different disciplines to focus research on ROS, which may lead finally to useful answers for the yet unanswered questions about this interesting orphan RTK.

\section{ACKNOWLEGEMENT}

This research was supported by Leading Technology Development Program funded by Small and Medium Business Administration, and a grant (K0006028) from the fundamental R\&D program for Core Technology of Materials funded by the Ministry of Knowledge Economy, Republic of Korea.

\section{REFERENCES}

1. Robinson DR, Wu, YM Lin, SF. The protein tyrosine kinase family of the human genome. Oncogene 2000;19:5548-5557.

2. Blume-Jensen P, Hunter T. Oncogenic kinase signaling. Nature 2001;411:355-365.

3. Kurzrock R, Gutterman JU, Talpaz M. The molecular genetics of Philadelphia chromosome positive leukemias. New Engl J Med 1988;319:990-998.

4. Falini B, Mason DY, Proteins encoded by genes involved in chromosomal alterations in lymphoma and leukemia: clinical value of their detection by immunocytochemistry. Blood 2002;99:409-426.

5. Druker BJ, Lydon NB. Lessons learned from the development of an Abl tyrosine kinase inhibitor for chronic myelogenous leukemia. J Clin Invest 2000;105:3-7.

6. Acquaviva J, Wong R, Charest A. The multifaceted roles of the receptor tyrosine kinase ROS in development and cancer. Biochim Biophys Acta 2009;1795:37-52.

7. Park BS, El-Deeb IM, Yoo KH, Oh CH, Cho SJ, Han DK, Lee HS, Lee JY, Lee SH. Design, synthesis and biological evaluation of new potent and highly selective ROS-tyrosine kinase inhibitor. Bioorg Med Chem Lett 2009;19:4720-4723. 
8. El-Deeb IM, Park BS, Jung SJ, Yoo KH, Oh CH, Cho SJ, Han DK, Lee JY, Lee SH. Design, synthesis, screening, and molecular modeling study of a new series of ROS receptor tyrosine kinase inhibitors. Bioorg Med Chem Lett 2009;19:5622-5626.

9. Balduzzi PC, Notter MFD, Morgan HR, Shibuya M. Some biological properties of two new avian sarcoma viruses. J Virol 1981;40:268-275.

10. Shibuya M, Hanafusa H, Balduzzi PC. Cellular sequences related to three new onc genes of avian sarcoma virus (fps, yes, and ROS) and their expression in normal and transformed cells. J Virol 1982;42:143-152.

11. Wang LH, Hanafusa H, Notter, MF, Balduzzi, PC. Genetic structure and transforming sequence of avian sarcoma virus UR2. J Virol 1982;41:833-841.

12. Neckameyer WS, Shibuya M, Hsu MT, Wang LH. Proto-oncogene c-ROS codes for a molecule with structural features common to those of growth factor receptors and displays tissue-specific and developmentally regulated expression. Mol Cell Biol 1986;6:1478-1486.

13. Matsushime H, Wang LH, Shibuya M. Human c-ROS gene homologous to the v-ROS sequence of UR2 sarcoma virus encodes for a transmembrane receptor-like molecule. Mol Cell Biol 1986;6:3000-3004.

14. Feldman RA, Wang LH, Hanafusa H, Balduzzi PC. Avian sarcoma virus UR2 encodes a transforming protein which is associated with a unique protein kinase activity. J Virol 1982;42:228-236.

15. Neckameyer WS, Wang LH. Nucleotide sequence of avian sarcoma virus UR2 and comparison of its transforming gene with other members of the tyrosine protein kinase oncogene family. J Virol 1985;53:879884.

16. Ullich A, Bell JR, Chen EY, Herrera R, Petruzzelli LM, Dull TJ, Gray A, Coussens L, Liao YC, Tsubokawa M, Mason A, Seeburg PH, Grunfeld C, Rosen OM, Ramachandran J. Human insulin receptor and its relationship to the tyrosine kinase family of oncogenes. Nature 1985;313:756-761.

17. Downward J, Yarden Y, Mayes E, Scrace G, Totty N, Stockwell P, Ullich A, Schlessinger J, Waterfield MD. Close similarity of epidermal growth factor receptor and v-erbB on oncogene protein sequences. Nature 1984;307:521-527.

18. Ebina Y, Ellins L, Jarnagin K, Edery M, Graf L, Clauser E, Ou J, Masiarz F, Kan YW, Goldfine ID, Roth RA, Rutter WJ. The human insulin receptor cDNA: the structural basis for hormone-activated transmembrane signalling. Cell 1985;40:747-758. 
19. Sherr CJ, Rettenmier CW, Sacca R, Roussel MF, Look TA, Stanly RE. The c-fms proto-oncogene product is related to the receptor for the mononuclear phagocyte growth factor, CSF-1. Cell 1985;41:665-676.

20. Matsushime H, Shibuya M. Tissue-specific expression of rat c-ROS-1 gene and partial structural similarity of its predicted products with sev protein of Drosophila melanogaster. J Virol 1990;64:2117-2125.

21. Birchmeier C, O'Neill K, Riggs M, Wigler M. Characterization of ROS cDNA from a human glioblastoma cell line. Proc Natl Acad Sci USA 1990;87:4799-4803.

22. Basler K, Hafen E. Control of photoreceptor cell fate by the sevenless protein requires a functional tyrosine kinase domain. Cell 1988;54:299-311.

23. Bowtell D, Simon M, Rubin G. Nucleotide sequence and structure of the sevenless gene of Drosophila melanogaster. Genes Dev 1988;2:620-634.

24. Bishop JM. Viral Oncogenes. Cell 1985;42:23-28.

25. Ullrich A, Coussens L, Hayflick JS, Dull TJ, Gray A, Tam AW, Lee J, Yarden Y, Libermann TA, Schlesinger J, Downward J, Mayes E, Whittle N, Waterfield M, Seeburg PH. Human epidermal growth factor receptor cDNA sequence and aberrant expression of the amplified gene in A431 epidermoid carcinoma cells. Nature 1984;309:418-425.

26. Sonnenberg E, Godecke A, Walter B, Bladt F, Birchmeier C. Transient and locally restricted expression of the ROS proto-oncogene during mouse development. EMBO J 1991;10:3693-3702.

27. Sonnenberg-Riethmacher E, Walter B, Riethmacher D, Godecke S, Birchmeier C. The c-ROS tyrosie kinase receptor controls regionalization and differentiation of epithelial cells in the epididymis. Genes Dev 1996;10:1184-1193.

28. Liu ZZ, Wada J, Kumar A, Carone FA, Takahashi M, Kanwar YS. Comparative role of phosphotyrosine kinase domains of c-ROS and c-ret proto-oncogenes in metanephric development with respect to growth factors and matrix morphogens. Dev Biol 1996;178:133-148.

29. Chen J, Zong CS, Wang LH. Tissue and epithelial cell-specific expression of chicken proto-oncogene c-ROS in several organs suggests that it may play roles in their development and mature functions. Oncogene 1994;9:773-780.

30. Légaré C, Sullivan R. Expression and localization of c-ROS oncogene along the human excurrent duct. Mol Hum Reprod 2004;10:697-703. 
31. Doolittle RF, Hunkapiller MW, Hood LE, Devare SG, Robbins KC, Aaronson SA, Antoniades HN. Simian sarcoma virus onc gene, v-sis, is derived from the gene or (genes) encoding a platelet-derived growth factor. Science 1983;222:275-277.

32. Waterfield MD, Scrace ST, Whittle N, Stroobant P, Johnson A, Wasteson A, Westermark B, Heldin CH, Huang JS, Deuel TF. Platelet-derived growth factor is structurally related to the putative transforming protein p28sis of simian sarcoma virus. Nature 1983;304:35-39.

33. Nagarajan L, Louie E, Tsujimoto Y, Balduzzi PC, Huebner K, Croce CM. The human c-ROS gene (ROS) is located at chromosome region 6q16 $\rightarrow$ 6q22. Proc Natl Acad Sci USA 1986;83:6568-6572.

34. Mitelman F. Chromosome 6. Cytogenet Cell Genet 1983;36:105-123.

35. Trent JM, Rosenfeld SB, Meyskens FL. Chromosome 6q involvement in human malignant melanoma. Cancer Genet Cytogenet 1983;9:177-180.

36. Atkin NB, Baker MC. Specific chromosome change in ovarian cancer. Cancer Genet Cytogenet 1981;3:275276.

37. Bigner SH, Humphrey PA, Wong AJ, Vogelstein B, Mark J, Friedman HS, Bigner DD. Characterization of the epidermal growth factor receptor in human glioma cell lines and xenografts. Cancer Res 1990;50:80178022.

38. Libermann TA, Nussbaum HR, Razon N, Kris R, Lax I, Soreq M, Whittle N, Waterfield MD, Ullrich A, Schlessinger J. Amplification, enhanced expression and possible rearrangement of the EGF-receptor in primary human brain tumors of glial origin. Nature 1985;313:144-147.

39. Wong AJ, Bigner SH, Bigner DD, Kinzler KW, Hamilton SR, Vogelstein B. Increased expression of the epidermal growth factor receptor gene in malignant gliomas is invariably associated with gene amplification. Proc Natl Acad Sci USA 1987;84:6899-6903.

40. Yamazaki H, Fukui Y, Ueyama Y, Tamaoki N, Kawamoto T, Taniguchi S, Shibuya M. Amplification of the structurally and functionally altered epidermal growth factor receptor gene (c-erbB) in human brain tumors. Mol Cell Biol 1988;8:1816-1820.

41. Bernstein JJ, Anagnostopoulos AV, Hattwick EA, Laws ER. J. Human-specific c-neu proto-oncogene protein overexpression in human malignant astrocytomas before and after xenografting. J Neurosurg 1993;78:240251. 
42. Gillaspy, GE, Mapstone TB, Samols D, Goldthwait DA. Transcriptional patterns of growth factors and protooncogenes in human glioblastomas and normal glial cells. Cancer Lett 1992;65:55-60.

43. Hayes C, Kelly D, Murayama S, Komiyama A, Suzuki K, Popko B. Expression of the neu oncogene under the transcriptional control of the myelin basic protein gene in transgenic mice: generation of transformed glial cells. J Neurosci Res 1992;31:175-187.

44. La Rocca RV, Rosenblum M, Westermark B, Israel MA. Patterns of proto-oncogene expression in human glioma cell lines. J Neurosci Res 1989;24:97-106.

45. Hermanson M, Funa K, Hartman M, Claesson-Welsh L, Heldin CH, Westermark B, Nister M, Plateletderived growth factor and its receptors in human glioma tissue: expression of messenger RNA and protein suggests the presence of autocrine and paracrine loops. Cancer Res 1992;52:3213-3219.

46. Nister M, Libermann TA, Betsholtz C, Pettersson M, Claesson-Welsh L, Heldin CH, Schlessinger J, Westermark, B. Expression of messenger RNAs for platelet-derived growth factor and transforming growth factor-alpha and their receptors in human malignant glioma cell lines. Cancer Res 1988;48:3910-3918.

47. Nister M, Claesson-Welsh L, Eriksson A, Heldin CH, Westermark B. Differential expression of plateletderived growth factor receptors in human malignant glioma cell lines. J Biol Chem 1991;226:16755-16763.

48. Lokker NA, Sullivan CM, Hollenbach SJ, Israel MA, Giese NA. Platelet-derived growth factor (PDGF) autocrine signaling regulates survival and mitogenic pathways in glioblastoma cells. Cancer Res 2002;62:3729-3735.

49. Birchmeier C, Sharma S, Wigler M. Expression and rearrangement of the ROS gene in human glioblastoma cells. Proc Natl Acad Sci USA 1987;84:9270-9274.

50. Mapstone T, McMichael M, Goldthwait D. Expression of platelet-derived growth factors, transforming growth factors, and the ROS gene in a variety of primary human brain tumors. Neurosurg 1991;28:216-222.

51. Watkins D, Dion F, Poisson M, Delattre JY, Rouleau GA. Analysis of onocogen expression in primary human gliomas: evidence for increased expression of the ROS onocogene. Cancer Genet Cytogenet 1994;72:130136.

52. Jun HJ, Woolfenden S, Coven S, Lane K, Bronson R, Housman D, Charest A. Epigenetic regulation of c-ROS receptor tyrosine kinase expression in malignant gliomas. Cancer Res 2009;69:2180-2184. 
53. Wu JK, Chikaraishi DM. Differential expression of ROS oncogene in primary human astrocytomas and astrocytoma cell lines. Cancer Res 1990;50:3032-3035.

54. Zhao JF, Sharma, S. Expression of the ROS oncogene for tyrosine receptor kinase in adult human meningiomas. Cancer Genet Cytogenet 1995;83:148-154.

55. Rikova K, Guo A, Zeng Q, Possemato A, Yu J, Haack H, Nardone J, Lee K, Reeves C, Li Y, Hu Y, Tan Z, Stokes, M, Sullivan L, Mitchell J, Wetzel R, MacNeill J, Ren JM, Yuan J, Bakalarski CE, Villen J, Kornhauser JM, Smith B, Li D, Zhou X, Gygi SP, Gu TL, Polakiewicz RD, Rush J, Comb MJ. Global survey of phosphotyrosine signaling identifies oncogenic kinases in lung cancer. Cell 2007;131:1190-1203.

56. Charest A, Wilker EW, McLaughlin ME, Lane K, Gowda R, Coven S, McMahon K, Kovach S, Feng Y, Yaffe MB, Jacks T, Housman D. ROS fusion tyrosine kinase activates a SH2 domain-containing phosphatase2/phosphatidylinositol 3-kinase/mammalian target of rapamycin signaling axis to form glioblastoma in mice. Cancer Res 2006;66:7473-7481.

57. Bhattacharjee A, Richards WG, Staunton J, Li C, Monti S. Vasa P. Ladd C, Beheshti J. Bueno R, Gillette M, Loda M, Weber G, Mark EJ, Lander ES, Wong W, Johnson BE, Golub TR, Sugarbaker DJ, Meyerson M. Classification of human lung carcinomas by mRNA expression profiling reveals distinct adenocarcinoma subclasses. Proc Natl Acad Sci USA 2001;98:13790-13795.

58. Bild AH, Yao G, Chang JT, Wang Q, Potti A, Chasse D, Joshi MB, Harpole D, Lancaster JM, Berchuck A, Olson Jr JA, Marks JR, Dressman HK, West M, Nevins JR. Oncogenic pathway signatures in human cancers as a guide to targeted therapies. Nature 2006;439:353-357.

59. Garber ME, Troyanskaya OG, Schluens K, Petersen S, Thaesler Z, Pacyna-Gengelbach M, van de Rijn M, Rosen GD, Perou CM, Whyte RI, Altman RB, Brown PO, Botstein D, Petersen I. Diversity of gene expression in adenocarcinoma of the lung. Proc Natl Acad Sci USA 2001;98:13784-13789.

60. Bonner AE, Lemon WJ, Devereux TR, Lubet RA, You M. Molecular profiling of mouse lung tumors: association with tumor progression, lung development, and human lung adenocarcinomas, Oncogene 2004;23:1166-1176.

61. Yamashita S, Nomoto T, Abe M, Tatematsu M, Sugimura T, Ushijima T. Persistence of gene expression changes in stomach mucosae induced by short-term N-methyl-N'-nitro-N-nitrosoguanidine treatment and their presence in stomach cancers. Mutat Res 2004;549:185-193. 
62. Eom M, Han A, Yi SY, Shin JJ, Cui Y, Park KH. RHEB expression in fibroadenomas of the breast. Pathol Int 2008;58:226-232.

63. Yovchev MI, Grozdanov PN, Joseph B, Gupta S, Dabeva MD. Novel hepatic progenitor cell surface markers in the adult rat liver. Hepatology 2007;45:139-149.

64. Yovchev MI, Grozdanov PN, Zhou H, Racherla H, Guha C, Dabeva MD. Identification of adult hepatic progenitor cells capable of repopulating injured rat liver. Hepatology 2008;47:636-647.

65. Ruhe JE, Streit S, Hart S, Wong CH, Specht K, Knyazev P, Knyazeva T, Tay LS, Loo HL, Foo P, Wong W, Pok S, Lim SJ, Ong H, Luo M, Ho HK, Peng K, Lee TC, Bezler M, Mann C, Gaertner S, Hoefler H, Iacobelli S, Peter S, Tay A, Brenner S, Venkatesh B, Ullrich A. Genetic alterations in the tyrosine kinase transcriptome of human cancer cell lines. Cancer Res 2007;67:11368-11376.

66. Zong CS, Poon B, Chen J, Wang LH. Molecular and biochemical bases for activation of the transforming potential of the proto-oncogene c-ROS. J Virol 1993;67:6453-6462.

67. Zong CS, Wang LH. Modulatory effect of the transmembrane domain of the protein-tyrosine kinase encoded by oncogene ROS: biological function and substrate interaction. Proc Natl Acad Sci USA 1994;91:1098210986.

68. Fasano O, Birnbaum D, Edlund L, Fogh J, Wigler M. New human transforming genes detected by a tumorigenicity assay. Mol Cell Biol 1984:4;1695-1705.

69. Birchmeier C, Birnbaum D, Waitches G, Fasano O, Wigler M. Characterization of an activated human ROS gene. Mol Cell Biol 1986;6:3109-3116.

70. Sara VR, Prisell P, Sjogren B, Persson L, Boethius J, Enberg G. Enhancement of insulin-like growth factor 2 receptors in glioblastoma. Cancer Lett 1986;32:229-234.

71. Fleming TP, Saxena A, Clark WC, Robertson JT, Oldfield EH, Aaronson SA, Ali IU. Amplification and/or overexpression of platelet-derived growth factor receptors and epidermal growth factor receptor in human glial tumors. Cancer Res 1992;52:4550-4553.

72. Trojan J, Blossey BK, Johnson TR, Rudin SD, Tykocinski M, Ilan J, Ilan J. Loss of tumorigenicity of rat glioblastoma directed by episome-based antisense cDNA transcription of insulin-like growth factor I. Proc Natl Acad Sci USA 1992;89:4874-4878. 
73. Smith JS, Wang XY, Qian J, Hosek SM, Scheithauer BW, Jenkins RB, James CD. Amplification of the platelet-derived growth factor receptor-A (PDGFRA) gene occurs in oligodendrogliomas with grade IV anaplastic features. J Neuropathol Exp Neurol 2000;59:495-503.

74. Charest A, Kheifets V, Park J, Lane K, McMahon K, Nutt CL, Housman D. Oncogenic targeting of an activated tyrosine kinase to the golgi apparatus in a glioblastoma. Proc Natl Acad Sci USA 2003;100:916-921.

75. Charest A, Lane K, McMahon K, Park J, Preisinger E, Conroy H, Housman D. Fusion of FIG to the receptor tyrosine kinase ROS in a glioblastoma with an interstitial del(6)(q21q21). Genes Chromosomes Cancer 2003;37:58-71.

76. Charest A, Lane K, McMahon K, Housman DE. Association of a novel PDZ domain-containing peripheral golgi protein with the Q-SNARE (Q-soluble N-ethylmaleimide-sensitive fusion protein (NSF) attachment protein receptor) protein syntaxin 6. J Biol Chem 2001;276:29456-29465.

77. Ponten J, Macintyre EH. Long term culture of normal and neoplastic human glia. Acta Pathol Microbiol Scand 1968;74:465-486.

78. Dang TP, Gazdar AF, Virmani AK, Sepetavec T, Hande KR, Minna JD, Roberts JR, Carbone DP. Chromosome 19 Translocation, Overexpression of notch3, and human lung cancer. J Natl Can Instit 2000;92:1355-1357.

79. Soda M, Choi YL, Enomoto M, Takada S, Yamashita Y, Ishikawa S, Fujiwara S, Watanabe H, Kurashina K, Hatanaka H, Bando M, Ohno S, Ishikawa Y, Aburatani H, Niki T, Sohara Y, Sugiyama Y, Mano H. Identification of the transforming EML4-ALK fusion gene in non-small cell lung cancer. Nature 2007;448:561-566.

80. Martelli MP, Sozzi G, Hernandez L, Pettirossi V, Navarro A, Conte D, Gasparini P, Perrone F, Modena P, Pastorino U, Carbone A, Fabbri A, Sidoni A, Nakamura S, Gambacorta M, Fernández PL, Ramirez J, Chan JKC, Grigioni WF, Campo E, Pileri SA, Falini B. EML4-ALK Rearrangement in Non-Small Cell Lung Cancer and Non-Tumor Lung Tissues. Am J Pathol 2009;174:661-670.

81. Ailan G, Anthony P. A translocation leading to a fusion protein of a ROS kinase and a sodium phosphate transporter in human non-small cell lung carcinoma. PCT Int. Appl. 2007, WO 2007084631 A2.

82. Ting-Lei G, Ailan G. A translocation leading to formation of a ROS kinase fusion protein with CD74 associated with human non-small cell lung carcinoma. PCT Int. Appl. 2009, WO 2009051846 A2. 
83. Murer H, Forster I, Biber J. The sodium phosphate cotransporter family SLC34, Pflugers Arch 2004;447:763767.

84. Rangel LB, Sherman-Baust CA, Wernyj RP, Schwartz DR, Cho KR, Morin PJ. Characterization of novel human ovarian cancer-specific transcripts (HOSTs) identified by serial analysis of gene expression. Oncogene 2003;22:7225-7232.

85. Leng L, Metz CN, Fang Y, Xu J, Donnelly S, Baugh J, Delohery T, Chen Y, Mitchell RA, Bucala R. MIF signal transduction initiated by binding to CD74. J Exp Med 2003;197:1467-1476.

86. Badve S, Deshpande C, Hua Z, Logdberg L. Expression of invariant chain (CD 74) and major histocompatibility complex (MHC) class II antigens in the human fetus. J Histochem Cytochem 2002;50:473482.

87. Mendelsohn J, Baselga J. Status of epidermal growth factor receptor antagonists in the biology and treatment of cancer. J Clin Oncol 2003;21:2787-2799.

88. Klampfer L. Signal transducers and activators of transcription (STATs): novel targets of chemopreventive and chemotherapeutic Drugs. Curr Cancer Drug Targets 2006;6:107-121.

89. Deng J, Grande F, Neamati N. Small molecule inhibitors of Stat3 signaling pathway. Curr Cancer Drug Targets 2007;7:91-107.

90. Mizoguchi M, Betensky RA, Batchelor TT, Bernay DC, Louis DN, Nutt CL. Activation of STAT3, MAPK, and AKT in malignant astrocytic gliomas: correlation with EGFR status, tumor grade, and survival. J Neuropathol Exp Neurol 2006;65:1181-1188.

91. Zong CS, Zeng L, Jiang Y, Sadowski HB, Wang LH. Stat3 plays an important role in oncogenic ROS- and insulin-like growth factor I receptor-induced anchorage-independent growth. J Biol Chem 1998;273:2806528072.

92. Wilson R, Ainscough R, Anderson K, Baynes C, Berks M, Bonfield J, Burton J, Connell M, Copsey T, Cooper J, Coulson A, Craxton M, Dear S, Du Z, Durbin R, Favello A, Fraser A, Fulton L, Gardner A, Green P, Hawkins T, Hillier L, Jier M, Johnston L, Jones M, Kershaw J, Kirsten J, Laisster N, Latreille P, Lightning J, Lloyd C, Mortimore B, O'Callaghan M, Parsons J, Percy C, Rifken L, Roopra A, Saunders D, Showedkeen R, Sims M, Smaldon N, Smith A, Smith M, Sonnhammer E, Staden R, Sulston J, Thierry-Mieg J, Thomas K, 
Vaudin M, Vaughan K, Waterston R, Watson A, Weinstock A, Wilkinson-Sproat J, Wohldman P. 2.2Mb of contiguous nucleotide sequence from chromosome III of C. elegans. Nature 1994;368:32-38.

93. Henske EP, Short MP, Jozwiak S, Bovey CM, Ramlakhan S, Haines JL, Kwiatkowski DJ. Identification of VAV2 on 9q34 and its exclusion as the tuberous sclerosis gene TSC1. Ann Hum Genet 1995;59:25-37.

94. Teramoto H, Salem P, Robbins KC, Bustelo XR, Gutkind JS. Tyrosine phosphorylation of the vav protooncogene product links FcRI to the Rac1-JNK pathway. J Biol Chem 1997;272:10751-10755.

95. Bustelo XR. The VAV family of signal transduction molecules. Crit Rev Oncog 1996;7:65-88.

96. Bustelo XR. Regulatory and signaling properties of the VAV family. Mol Cell Biol 2000;20:1461-1477.

97. Movilla N, Bustelo XR. Biological and regulatory properties of VAV-3, a new member of the VAV family of oncoproteins. Mol Cell Biol 1999;19:7870-7885.

98. Trenkle T, McClelland M, Adlkofer K, Welsh J. Major transcript variants of VAV3, a new member of the VAV family of guanine nucleotide exchange factors. Gene 2000;245:139-149.

99. Zeng L, Sachdev P, Yan L, Chan JL, Trenkle T, McClelland M, Welsh J, Wang LH. VAV3 mediates receptor protein tyrosine kinase signaling, regulates GTPase activity, modulates cell morphology, and induces cell transformation. Mol Cell Biol 2000;20:9212-9224.

100. Nguyen KT, Zong CS, Uttamsingh S, Sachdev P, Bhanot M, Le MT, Chan JL, Wang LH. The role of phosphatidylinositol 3-kinase, rho family GTPases, and STAT3 in ROS-induced cell transformation, J Biol Chem 2002;277:11107-11115.

101. Morgan TM, Koreckij TD, Corey E. Targeted therapy for advanced prostate cancer: Inhibition of the PI3K/Akt/mTOR pathway. Curr Cancer Drug Targets 2009;9:237-249.

102. Fulda S. The PI3K/Akt/mTOR Pathway as therapeutic target in neuroblastoma. Curr Cancer Drug Targets 2009;9:729-737.

103. Tokunaga E, Oki E, Egashira A, Sadanaga N, Morita M, Kakeji Y, Maehara Y. Deregulation of the Akt pathway in human cancer. Curr Cancer Drug Targets 2008;8:27-36.

104. de Souza PL, Russell PJ, Kearsley J. Role of the Akt pathway in prostate cancer. Curr Cancer Drug Targets 2009;9:163-175. 
105. Uttamsingh S, Zong CS, Wang LH. Matrix-independent activation of phosphatidyl-inositol 3-kinase, Stat3, and cyclin A-associated Cdk2 is essential for anchorage-independent growth of v-ROS-transformed chicken embryo fibroblasts. J Biol Chem 2003;278:18798-18810.

106. Zong CC, Chan JL, Yang SK, Wang LH. Mutations of ROS differentially effecting signal transduction pathways leading to cell growth versus transformation. J Biol Chem 1997;272:1500-1506.

107. Rao RD, Buckner JC, Sarkaria JN. Mammalian target of rapamycin (m-TOR) inhibitors as anti-cancer agents. Curr Cancer Drug Targets 2004;8:621-635.

108. Shen SH, Bastien L, Posner BI, Chretien P. A protein-tyrosine phosphatase with sequence similarity to the SH2 domain of the protein-tyrosine kinases. Nature 1991;352:736-739.

109. Wang N, Li Z, Ding R, Frank GD, Senbonmatsu T, Landon EJ, Inagami T, Zhao ZJ. Antagonism or synergism: role of tyrosine phosphatases SHP-1 and SHP-2 in growth factor signaling. J Biol Chem 2006;281:21878-21883.

110. Shultz LD, Coman DR, Bailey CL, Beamer WG, Sidman CL. "Viable motheaten," a new allele at the motheaten locus. I. Pathology. Am J Pathol 1984;116:179-192.

111. Keilhack H, Müller M, Böhmer SA, Frank C, Weidner KM, Birchmeier W, Ligensa T, Berndt A, Kosmehl H, Günther B, Müller T, Birchmeier C, Böhmer FD. Negative regulation of ROS receptor tyrosine kinase signaling: an epithelial function of the SH2 domain protein tyrosine phosphatase SHP-1. J Cell Biol 2001;152:325-334.

112. Biskup C, Böhmer A, Pusch R, Kelbauskas L, Gorshokov A, Majoul I, Lindenau J, Benndorf K, Böhmer FD. Visualization of SHP-1-target interaction. J Cell Sci 2004;117:5165-5178.

113. Imhof D, Nothmann D, Zoda MS, Hampel K, Wegert J, Bohmer FD, Reissmann S. Synthesis of linear and cyclic phosphopeptides as ligands for the N-terminal SH2-domain of protein tyrosine phosphatase SHP-1. J Pept Sci 2005;11:390-400.

114. Imhof D, Wieligmann K, Hampel K, Nothmann D, Zoda MS, Schmidt-Arras D, Zacharias M, Bhmer FD, Reissmann S. Design and biological evaluation of linear and cyclic phosphopeptide ligands of the N-terminal SH2 domain. J Med Chem 2005;48:1528-1539. 
115. Loh ML, Vattikuti S, Schubbert S, Reynolds MG, Carlson E, Lieuw KH, Cheng JW, Lee CM, Stokoe D, Bonifas JM, Curtiss NP, Gotlib J, Meshinchi S, Le Beau MM, Emanuel PD, Shannon KM. Mutations in PTPN11 implicate the SHP-2 phosphatase in leukemogenesis, Blood 2004;103:2325-2331.

116. Tartaglia M, Martinelli S, Cazzaniga G, Cordeddu V, Iavarone I, Spinelli M, Palmi C, Carta C, Pession A, Arico, M, Masera G, Basso G, Sorcini M, Gelb BD, Biondi A. Genetic evidence for lineage-related and differentiation stage-related contribution of somatic PTPN11 mutations to leukemogenesis in childhood acute leukemia. Blood 2004;104:307-313.

117. Tartaglia M, Niemeyer CM, Shannon KM, Loh ML. SHP-2 and myeloid malignancies. Curr Opin Hematol 2004;11:44-50.

118. Bentires-Alj M, Paez JG, David FS, Keilhack H, Halmos B, Naoki K, Maris JM, Richardson A, Bardelli A, Sugarbaker DJ, Richards WG, Du J, Girard L, Minna JD, Loh ML, Fisher DE, Velculescu VE, Vogelstein B, Meyerson M, Sellers WR, Neel BG. Activating mutations of the noonan syndrome-associated SHP2/PTPN11 gene in human solid tumors and adult acute myelogenous leukemia. Cancer Res 2004;64:8816-8820.

119. Noguchi T, Matozaki T, Horita K, Fujioka Y, Kasuga M. Role of SH-PTP2, a protein-tyrosine phosphatase with Src homology 2 domains, in insulin stimulated Ras activation. Mol Cell Biol 1994;14:6674-6682.

120. Saxton TM, Ciruna BG, Holmyard D, Kulkarni S, Harpal K, Rossant J, Pawson T. The SH2 tyrosine phosphatase shp2 is required for mammalian limb development. Nat Genet 2000;24:420-423.

121. Zhan Y, O'Rourke DM. SHP-2-dependent mitogen-activated protein kinase activation regulates EGFRvIII but not wild-type epidermal growth factor receptor phosphorylation and glioblastoma cell survival. Cancer Res 2004;64:8292-8298.

122. Shiffman D, Ellis SG, Rowland CM, Malloy MJ, Luke MM, Iakoubova OA, Pullinger CR, Cassano J, Aouizerat BE, Fenwick RG, Reitz RE, Catanese JJ, Leong DU, Zellner C, Sninsky JJ, Topol EJ, Devlin JJ, Kane JP. Identification of four gene variants associated with myocardial infarction. Am J Hum Genet 2005;77:596-605.

123. Zee RYL, Michaud SE, Hengener HH, Diehl KA, Ridker PM. A prospective replication study of five gene variants previously associated with risk of myocardial infarction. J Thromb Haemost 2006;4:2093-2095. 
124. Horne BD, Carlquist JF, Muhlestein JB, Nicholas ZP, Anderson JL. Associations with myocardial infarction of six polymorphisms selected from a three-stage genome-wide association study. Am Heart J 2007;154:969975.

125. Koch W, Hoppmann P, Schömig A, Kastrati A. Variations of specific non-candidate genes and risk of myocardial infarction: a replication study. Int J Cardiol 2009, in press.

126. Oguri M, Kato K, Hibino T, Yokoi K, Segawa T, Matsuo H, Watanabe S, Nozawa Y, Murohara T, Yamada Y. Genetic risk for restenosis after coronary stenting. Atherosclerosis 2007;194:172-178.

127. Yamada Y, Kato K, Yoshida T, Yokoi K, Matsuo H, Watanabe S, Ichihara S, Metoki N, Yoshida H, Satoh K, Aoyagi Y, Yasunaga A, Park H, Tanaka M, Nozawa Y. Association of polymorphisms of ABCA1 and ROS with hypertension in Japanese individuals. Int J Mol Med 2008;21:83-89.

128. Yamada Y, Kato K, Oguri M, Yoshida T, Yokoi K, Watanabe S, Metoki N, Yoshida H, Satoh K, Ichihara S, Aoyagi Y, Yasunaga A, Park H, Tanaka M, Nozawa, Y. Association of genetic variants with atherothrombotic cerebral infarction in Japanese individuals with metabolic syndrome. Int J Mol Med 2008;21:801-808.

129. Yamada Y, Metoki N, Yoshida H, Satoh K, Kato K, Hibino T, Yokoi K, Watanabe S, Ichihara S, Aoyagi Y, Yasunaga A, Park H, Tanaka M, Nozawa Y. Genetic factors for ischemic and hemorrhagic stroke in Japanese individuals. Stroke 2008;9:2211-2218.

130. Yeung CH, Sonnenberg-Riethmacher E, Cooper TG. Infertile spermatozoa of c-ROS tyrosine kinase receptor knockout mice show flagellar angulation and maturational defects in cell volume regulatory mechanisms. Biol Reprod 1999;61:1062-1069.

131. Yeung CH, Wagenfeld A, Nieschlag E, Cooper TG. The cause of infertility of male c-ROS tyrosine kinase receptor knockout mice. Biol Reprod 2000;63:612-618.

132. Smith TT, Yanagimachi R. The viability of hamster spermatozoa stored in the isthmus of the oviduct: the importance of sperm-epithelium contact for sperm survival. Biol Reprod 1990;42:450-457.

133. Smith TT, Yanagimachi R. Attachment and release of spermatozoa from the caudal isthmus of the hamster oviduct. J Reprod Fertil 1991;91:567-573.

134. Demott RP, Lefebvre R, Suarez SS. Carbohydrates mediate the adherence of hamster sperm to oviductal epithelium. Biol Reprod 1995;52:1395-1403. 
135. Lefebvre R, Suarez SS. Effect of capacitation on bull sperm binding to homologous oviductal epithelium. Biol Reprod 1996;54:575-582.

136. Esponda P, Moreno M. Acrosomal status of mouse spermatozoa in the oviductal isthmus. J Exp Zool 1998;282:360-366.

137. Smith TT. The modulation of sperm function by the oviductal epithelium. Biol Reprod 1998;58:1102-1104.

138. Yeung CH, Anapolski M, Cooper TG. Measurement of volume changes in mouse spermatozoa using an electronic sizing analyzer and a flow cytometer: validation and application to an infertile mouse model. J Androl 2002;23:522-528.

139. Yeung CH, Anapolski M, Sipila P, Wagenfeld A, Poutanen M, Huhtaniemi I, Nieschlag E, Cooper TG. Sperm volume regulation: maturational changes in fertile and infertile transgenic mice and association with kinematics and tail angulation. Biol Reprod 2002;67:269-275.

140. Wagenfeld A, Yeung CH, Lehnert W, Nieschlag E, Cooper TG. Lack of glutamate transporter EAAC1 in the epididymis of infertile c-ROS receptor tyrosine kinase-deficient mice. J Androl 2002;23:772-782.

141. Yeung CH, Breton S, Setiawan I, Xu Y, Lang F, Cooper TG. Increased luminal pH in the epididymis of infertile c-ROS knockout mice and the expression of sodium-hydrogen exchangers and vacuolar proton pump H+-ATPase. Mol Reprod Dev 2004;68:159-168.

142. Yeung CH, Anapolski M, Setiawan I, Lang F, Cooper TG. Effects of putative epididymal osmolytes on sperm volume regulation of fertile and infertile c-ROS transgenic mice. J Androl 2004;25: 216-223.

143. Banerjee P. Recognition of c-ROS oncogene inhibition with a FRET-based receptor construct. MURJ, 2004;10:52-57.

144. Karaman MW, Herrgard S, Treiber DK, Gallant P, Atteridge CE, Campbell BT, Chan KW, Ciceri1 P, Davis MI, Edeen PT, Faraoni1 R, Floyd M, Hunt JP, Lockhart DJ, Milanov ZV, Morrison MJ, Pallares G, Patel HK, Pritchard S, Wodicka LM, Zarrinkar PP. A quantitative analysis of kinase inhibitor selectivity. Nat Biotechnol 2008;26:127-132.

145. Reaction Biology Corporation web site, http://www.reactionbiology.com/Kinases/ROS.pdf.

146. Glienke W, Maute L, Koehl U, Esser R, Milz E, Bergmann L. Effective treatment of leukemic cell lines with wt1 siRNA. Leukemia 2007;21:2164-2170. 
147. Wang H, Tan SS, Wang XY, Liu DH, Yu CS, Bai ZL, He DL, Zhao J. Silencing livin gene by siRNA leads to apoptosis induction, cell cycle arrest, and proliferation inhibition in malignant melanoma LiBr cells. Acta Pharmacol Sin 2007;28:1968-1974.

148. D'Astolfo DS, Gehrau RC, Bocco JL, Koritschoner NP. Silencing of the transcription factor KLF6 by siRNA leads to cell cycle arrest and sensitizes cells to apoptosis induced by DNA damage. Cell Death Differ 2008;15:613-616.

149. Li SD, Chono S, Huang L. Efficient oncogene silencing and metastasis inhibition via systemic delivery of siRNA. Mol Ther 2008;16:942-946.

150. Gonzalez-Gonzalez E, Ra H, Hickerson RP, Wang Q, Piyawattanametha W, Mandella MJ, Kino GS, Leake D, Avilion AA, Solgaard O, Doyle TC, Contag CH, Kaspar RL. siRNA silencing of keratinocyte-specific GFP expression in a transgenic mouse skin model. Gene Ther 2009;16:963-972. 

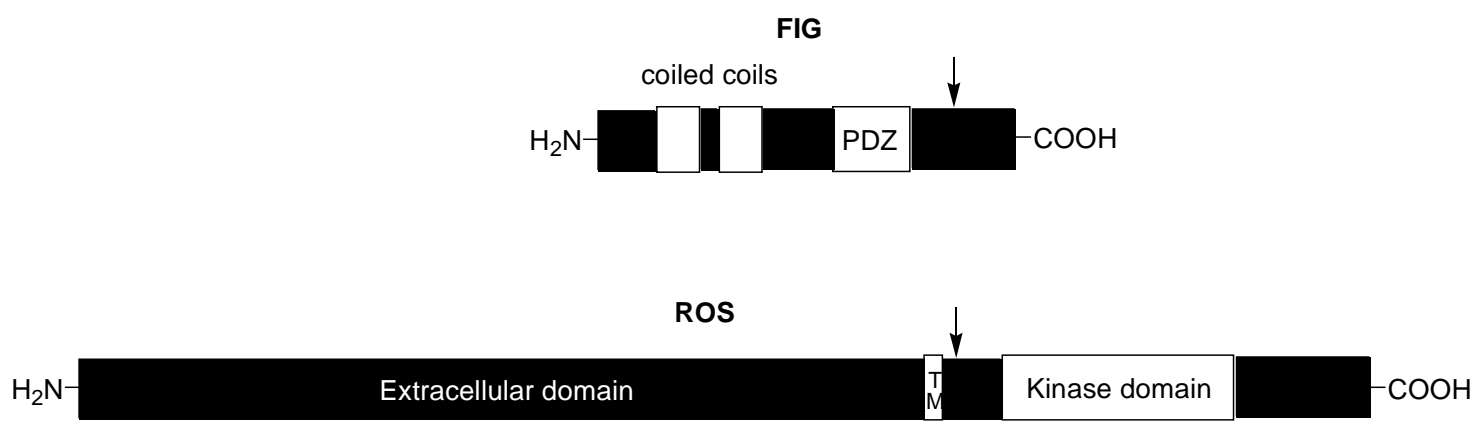

FIG-ROS Fusion (878 aa)

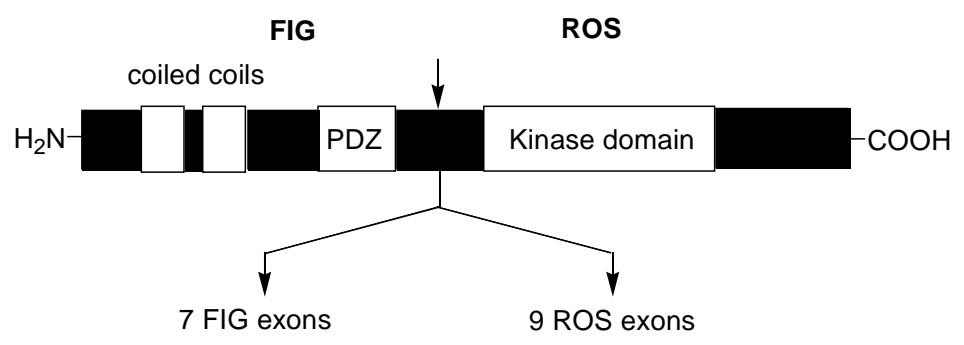

Figure 1. FIG-ROS gene translocation 
A
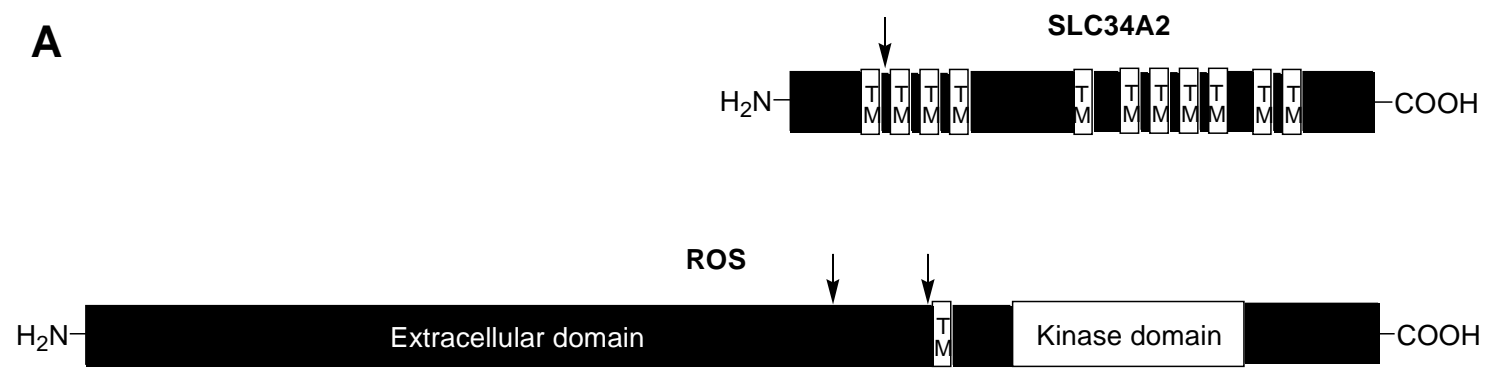

SLC34A2-ROS (Long transcript, 724aa)

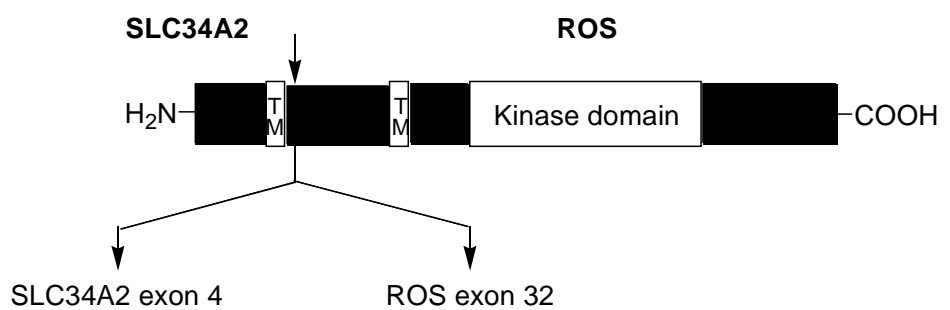

SLC34A2-ROS (Short transcript, 621aa)

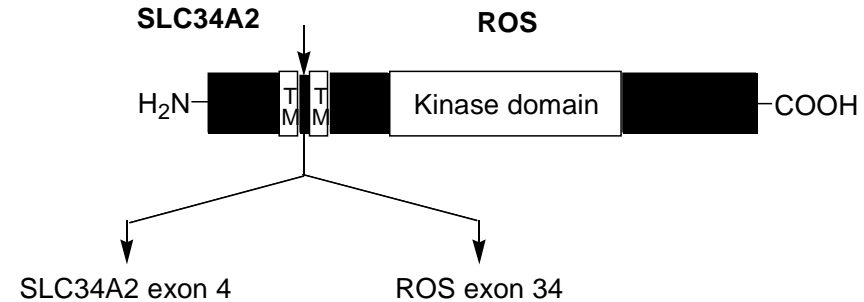

B
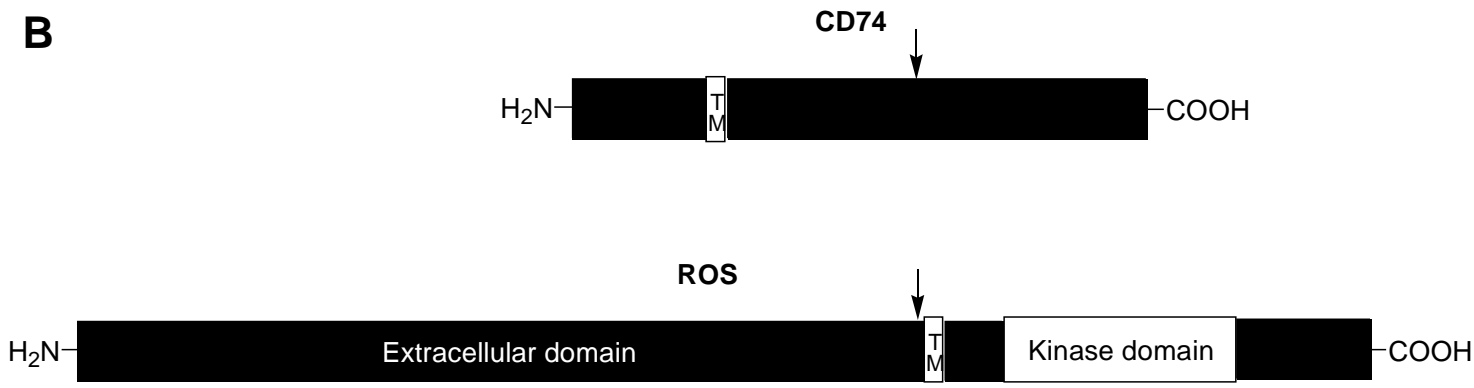

CD74-Ros fusion (703 aa)

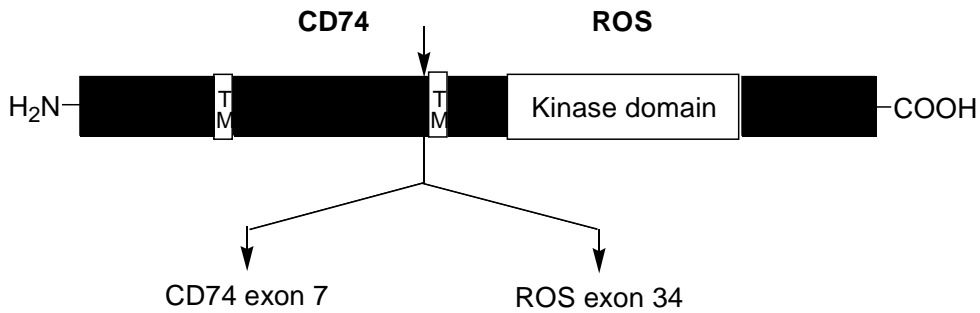

Figure 2. SLC34A2-ROS (A) and CD74-ROS (B) gene translocations 


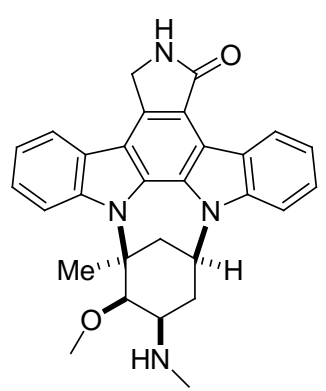

staurosporine

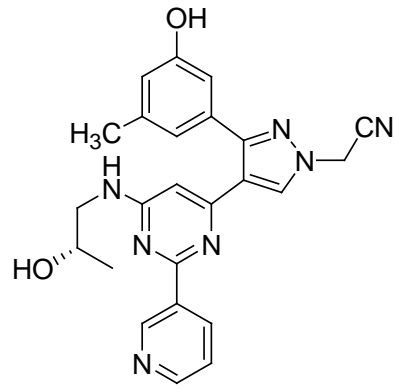

KIST301072<smiles>Cc1cc(O)cc(-c2nn(CC#N)cc2-c2ccnc(-c3cccnc3)c2)c1</smiles>

KIST301080<smiles>CCN1CCN(Cc2ccc(NC(=O)Nc3ccc(Oc4cc(NC)ncn4)cc3)cc2C(F)(F)F)CC1</smiles>

AST-487

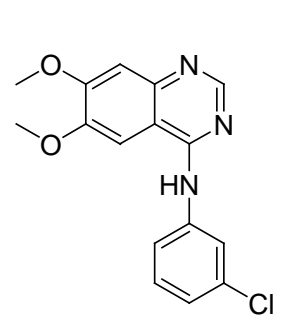<smiles>COc1cc2ncnc(N3CCN(C(=O)Nc4ccc(Oc5ccccc5)cc4)CC3)c2cc1OC</smiles>

PDGFR I-III<smiles>CC(C)(C)n1nc(-c2ccc(Cl)cc2)c2c(N)cccc21</smiles>

PP 2

AG 1478

Figure 3. The structures of compounds screened against ROS kinase. 
Table I. IC $_{50}$ values of ROS kinase inhibitors by enzyme-based screening

\begin{tabular}{cccc}
\hline Inhibitors & Selectivity & IC $_{50}(\mathrm{nM})$ & Reference \\
\hline Staurosporine & non-selective & 0.9 & 144 \\
KIST301072 & selective & 199 & 7 \\
KIST301080 & selective & 209 & 8 \\
AST-487 & non-selective & 1,700 & 143 \\
PP 2 & non-selective & 5,200 & 144 \\
AG 1478 & non-selective & 13,600 & 144 \\
PDGFR I-III & non-selective & 48,000 & 144 \\
D-64406 & non-selective & 365,000 & 144 \\
\hline
\end{tabular}


Table II. \% Enzymatic inhibitions exerted by KIST301072

\begin{tabular}{|c|c|c|c|}
\hline Kinase Enzyme & $\%$ Inhibition $^{\mathrm{a}}$ & Kinase Enzyme & \% Inhibition ${ }^{\mathrm{a}}$ \\
\hline ABL1 & 20.44 & JNK1a1 & 3.83 \\
\hline AKT1 (dPH, S473D) & -2.97 & KDR/VEGFR2 & -5.84 \\
\hline Aurora A & 21.75 & LCK & 10.28 \\
\hline BRAF & 8.97 & LYN & -1.45 \\
\hline CDK1/cyclinB & 3.64 & MEK1 & -6.97 \\
\hline CHK1 & 2.36 & MST4 & -1.54 \\
\hline CK1epsilon & 9.32 & MUSK & -0.42 \\
\hline c-Kit & 2.85 & P38a/MAPK14 & 5.27 \\
\hline c-MET & 5.82 & p70S6K & 5.79 \\
\hline c-Src & 16.18 & PAK4 & 1.37 \\
\hline DAPK1 & -1.17 & PIM1 & 5.91 \\
\hline DNA-PK & 6.56 & PKCa & 9.23 \\
\hline EGFR & -2.23 & PLK1 & 5.85 \\
\hline EPHA1 & 23.27 & RAF1 & 20.39 \\
\hline FAK/PTK2 & 3.43 & RET & 6.65 \\
\hline FGFR1 & -8.05 & ROCK1 & 11.72 \\
\hline FGR & 3.34 & RON/MST1R & 28.82 \\
\hline FLT1 & -1.67 & ROS & 93.92 \\
\hline FYN & -7.86 & SYK & 8.23 \\
\hline HIPK1 & -3.43 & TIE2/TEK & 8.17 \\
\hline IKKa/CHUK & 1.37 & TRKA/NTRK1 & -0.14 \\
\hline IR & 7.01 & YES & -2.59 \\
\hline JAK1 & 9.15 & & \\
\hline
\end{tabular}

${ }^{\mathrm{a}}$ Test compound was used in a single dose concentration of $10 \mu \mathrm{M}$. 


\begin{tabular}{ll}
\hline \multicolumn{1}{c}{ Application } & \multicolumn{1}{c}{ Verification Methods } \\
\hline Anticancer drugs & $\begin{array}{l}\text { Evaluate the ability of the inhibitors to inhibit the growth of cancer } \\
\text { cell lines and in vivo engineered tumor models that are harboring } \\
\text { ROS mutations }\end{array}$ \\
Discovery of cell-lines harboring & $\begin{array}{l}\text { Evaluate the inhibitory effect of the inhibitors over a large panel of } \\
\text { suspected cell lines utilizing the selective responsiveness of cells } \\
\text { ROS mutations }\end{array}$ \\
harboring ROS mutations \\
Evaluate Contraceptives & $\begin{array}{l}\text { wild male mice similar to that produced in c-ROS knockout mice } \\
\text { Breatment of ROS-induced CV }\end{array}$ \\
diseases & diseases.
\end{tabular}

Table III. Potential clinical applications of ROS kinase inhibitors 


\section{Biosketch}

Ibrahim Mustafa El-Deeb obtained his Bachelor of Pharmaceutical Sciences from Mansoura University, Egypt in 2001. In 2006 he earned his MS degree in Medicinal Chemistry from the same University. Now, he is a $3^{\text {rd }}$ year Ph.D. student in the University of Science and Technology, South Korea, under the direction of Dr. So Ha Lee. He has been actively involved in the design and synthesis of kinase inhibitors as anticancer agents.

Kyung Ho Yoo received his Ph.D. degree in organic chemistry from Korea Advanced Institute of Science and Technology, Korea, in 1992. Subsequently, he did post-doctoral work at The Johns Hopkins University, USA. Currently he is working as a senior researcher at Korea Institute of Science and Technology, Korea. His research interests focused on the development of novel therapeutic agents for the treatment of cancer and neurodegenerative diseases.

So Ha Lee was born in 1962 in Kongju, Korea. He received his PhD from Korea University in 1999 for work on the synthesis of bisoxazine ligands and 3-substituted piperidine ligands, and their enantioselective reactions, supervised by Professor Bong Young Chung. From 1987-1989, he worked at the Korea Institute of Energy and Resources; from 1991 to the present time, he has been based at the Korea Institute of Science and Technology as a senior researcher. His research interests include the synthesis of biologically active the novel drugs utilizing chemical synthesis and natural product. 